\title{
Financial Sector Regulation and the Revolving Door in US Commercial banks*
}

\author{
ELISE S. BREZIS \\ Jö̈l CARIOLle
}

Elise S. Brezis is Professor of Economics at Bar-Ilan University. She is the director of the Azrieli Center for Economic Policy. She holds a PhD in Economics from MIT (1989). She has published articles in leading journals as the American Economic Review and the European Economic Review, in the Oxford Encyclopedia and in the New Palgrave. Her research interests are related to economic growth. E-mail : elise.brezis@biu.ac.il

Joël Cariolle is Research Officer at Ferdi. He has a Ph.D in Economics from the CERDI-University of Auvergne (Clermont-Ferrand, France). His researches focus on regional integration in sub-Saharan African countries, economic vulnerability in Least Developed Countries, and corruption prevalence in developing and developed countries.

E-mail : joel.cariolle@ferdi.fr

\section{Introduction}

The "revolving door" is a practice quite widely in use in the United States, in which heads of state agencies, after completing their bureaucratic terms, are entering the very sector they have regulated. This phenomenon is also frequent in France, where it is coined "pantouflage", and in Japan, coined "amakudari" (descent from heaven). Research conducted and data collected by the research group Corporate Europe Observatory strongly suggest that this process is also significant within EU institutions'. In the last two decades, the revolving door and the intertwining relations between governments and private groups have intensified. The revolving door became so widespread in the financial sector that it has been pointed out by the OECD (2009) and NGO's (Transparency International-UK, 2011) as a major cause of the 2008 financial crisis. 
In its 2009 report on the revolving door and the financial crisis, the OECD therefore stressed the necessity to set appropriate rules and procedures to control conflicts of interest generated by this phenomenon (OECD, 2009). ${ }^{2}$

The revolving door affects the economy through two main channels: a positive one as well as a negative one. On the one hand, this movement of individuals between the public and private sectors may lead to some positive effects and can be desirable. Indeed, the revolving door allows recruiting qualified bureaucrats, and the knowledge the bureaucrat has accumulated while working in the public sector is put in use in their future position.

On the other hand, the revolving door is a recruitment process leading to distortive effects due to strong risk of conflicts of interest and state capture. In fact, in countries where explicit bribes cannot be paid safely, it is an important vehicle for corrupt deals with negative consequences on the economy, leading to lenient regulations which encouraged crisis as in 2008 , as emphasized by the OECD (2009) and Transparency International-UK (2011).

The purpose of this paper is to present a proxy for the distortive effect of the revolving door - the Revolving Door Index (RDI) - in the financial sector. This index will permit to raise awareness on the need of regulating the revolving door process and preventing conflicts of interests that have led to the financial crisis.

The distortive effects of the revolving door stem from the concentration of former regulators in a small number of firms. These "politically-connected firms" through the revolving door will gain significant advantage over their "non-connected" competitors, by benefitting from a wide range of preferential treatments: tailored regulations, lenient regulatory oversight, biased procurement processes, and so on. In fact, the literature widely emphasizes how politically-connected firms can capture regulations and regulatory agencies. As a consequence, our index is derived from a Herfindahl formula, which has the particularity to pinpoint concentration of former regulators among firms. After having defined this index, we calculate it for the top-five US commercial banks. ${ }^{3}$

The paper is divided in five parts. In section 2, we present the related literature and detail the distortionary effects of the revolving door. The literature stresses that state capture and conflicts of interests induced by the revolving door can take different forms. We more specifically focus on the public resources misallocation and unfair competition between connected and less connected firms. We also focus on how the difference in leniency of regulators towards the various firms can lead to crisis and bubbles.

Section 3 presents a small model illustrating how there can be concentration of revolvers in some specific firms, and how this inequality between firms can affect their profits. We develop the notion

\footnotetext{
${ }^{2}$ See also www.opensecrets.org. on the revolving door inside the US financial sector. See also Transparency InternationalUK (2011) and Transparency International (2010), which lay down the negative as well as positive effects of the Revolving door.

${ }^{3}$ We should underline that this is the first attempt to develop an index related to the revolving door, since we did not find another attempt in the literature to develop such an index.
} 
of bureaucratic capital, which is a way for public regulators to get high revenues in the private sector, and a way for firms to get influence over regulatory agencies.

In section 4, we develop our Revolving Door Index. In part 5, we propose an empirical illustration of the index using data on the revolving door in the five biggest US commercial banks. Part 6 presents some policy conclusions related to the regulation of the financial sector.

\section{The literature}

The literature on the revolving door, and its effects on the economy, is quite diverse. We divide this literature in three main related subjects: studies addressing firm's performance; those focusing on corruption prevalence; and those documenting distortions created by the revolving door. The rationale behind these different aspects is that the revolving door positively influences firms' market valuation, but this 'over'-value very often results from rent-seeking (including corruption), thereby generating economic distortions in the economy.

\subsection{Revolving door, political connections, and firms' performances}

The literature on the effects of the revolving door on firms' performance is part of a broader literature emphasizing the effects of political connections on firms' performances and aggregate outcomes. It focuses on the value for specific firms of different types of connections, which include campaign contributions (Classens et al. 2008), personal relationships (Amore and Bennedsen, 2013; Johnson and Mitton, 2003), political party membership (Khwaja and Mian, 2005), and the revolving doors (Faccio, 2006, Luechinger and Moser, 2014).

In emerging and industrialized economies, where relationships linked to kinship, friendship, or ethnicity have been progressively replaced by market-based relationships in economic exchanges (Rajan and Zingales 1998; Andvig 2006), the revolving door is a major source of political connections with significant positive effects on firms' value (Faccio 2006; Cingano and Pinotti 2013; Kramarz and Thesmar 2013; Goldman et al. 2013; Luechinger and Moser 2014).

The revolving door brings value to the firm through two separated types of movements of individuals between public agencies and regulated private entities. The first movement involves regulators (ministers, legislators, high-level officers, advisers) who leave the public sector to enter the private sector they have regulated. The second involves employees of regulated companies entering the government, the Parliament, or key regulatory agencies.

On the theoretical side, the expected effects of the revolving door on firms' value can be derived from the theoretical rent-seeking models emphasizing the allocation of talents between productive activities and unproductive rent-seeking activities (Murphy et al, 1991; Cingano and Pinotti, 2013). This literature focuses mainly on the movement from the public sector towards the 
private one, and stresses that the revolving door may increase firm's performances via two competing channels:

1. the productive channel or "schooling hypothesis": the revolving door is used to increase firm's productivity because revolved regulators may be more skilled and familiar with the regulations.

2. the rent-seeking channel or "quid-pro-quo hypothesis": the revolving door is used to capture public resources, through legal and illegal means, and increases the value of the firm without increasing efficiency. Under the quid-pro-quo hypothesis, politically-connected firms through the revolving door therefore benefit from preferential treatments, which are sources of economic distortions.

Do empirical evidences support the prevalence of the rent-seeking or the productive channel?

About the productive channel, except for Lucca et al. (2014) who provide evidence which tend to support the "schooling hypothesis" in the banking sector, most empirical studies tend to invalidate the hypothesis of a productive revolving door process. Cingano and Pinotti (2013), using a sample of Italian firms, have shown that corporate appointments of local politicians do not increase firms' productivity. Kramarz and Thesmar (2013), and Bertrand et al. (2006) show that French firms politically-connected through their CEOs and directors tend to overpay them, are less likely to fire them if they underperform, are associated with poorer accounting performances and excessive employment rates, and make bigger and worse acquisitions. Moreover, Slinko et al. (2005) find that politically-powerful Russian firms adversely affect the performance of small or politically-powerless firms, by getting administrations creating excessive regulation over the latter and by diverting government spending. By contrast, they find that politically-powerless firms invest more and are more productive in regions where the concentration of firms' political power is lower.

About the rent-seeking channel, empirical studies suggest that the revolving door affects the allocation of resources in the economy through three mains areas: i) public procurement, ii) access to finance and iii) tax exemptions.

Regarding public procurement, the revolving door gives firms the power of diverting state resources by biasing public procurement process. Indeed, Goldman et al. (2013) show that, following the 1994 House and Senate election, the presence of former politicians affiliated to the winning (losing) political party at the boards of U.S companies increases (decreases) the total value of awarded public procurement contracts.

In a similar vein, Cingano and Pinotti (2013) show that corporate appointments of local Italian politicians shift public demand toward connected firms, especially in high public expenditure and high corruption provinces, and that this shift reduces public good provision by $20 \%$.

About the access to finance, a great body of the literature emphasizes that firms using the revolving door are associated with a preferential access to finance (Khwaja and Mian, 2005; Boubakri et al, 2012) and are more likely to be bailed out after financial distress (Faccio et al., 2006). 
The revolving door also affects benefits from government allocations. Country-level empirical studies suggest that firms engaged in the revolving door are likely to use their influence so as to benefit from tax exemption and subsidy allowance. Slinko et al. (2005) show that politically influential firms in Russia are allowed to accumulate more arrears in tax, supplier, and wage payments than their non-connected counterparts. Faccio (2010) also shows that politically connected firms pay lower tax than other firms. ${ }^{4}$

In summary, the literature supports that politically connected firms through the revolving door are unlikely to be productive, are likely to shape and law and regulations and divert state resources to their own benefit, and to reduce overall productivity in the private and the public sectors.

\subsection{Revolving door and corruption}

Transparency International (2011) and the OECD (2009) pointed out that the revolving door may induce various schemes of conflicts of interest, during and after regulators' term in public office, thereby generating unlawful behavior. Moreover, the revolving door is also related to lawful but unethical behavior termed "legal corruption" by Kaufmann and Vicente (2011). Kaufmann has referred this behavior to: "efforts by companies and individuals to shape law or policies to their advantage, often done quasi-legally, via campaign finance, lobbying or exchange of favors to politicians, regulators and other government officials. [...] In its more extreme form, legal corruption can lead to control of entire states, through the phenomenon dubbed 'state capture,' and result in enormous losses for societies." ${ }^{\prime 6}$

As an indication of the strong link between the revolving door process and corrupt practices, crosscountry analyses (Faccio, 2006, 2010) and case studies (Cingano and Pinotti, 2013; Slinko et al, 2005) have shown that the differential in economic returns between connected and nonconnected firms increases in high corruption environments.

More specifically, connected firms through the revolving door may derive undue advantages by legally and illegally influencing the formulation, adoption, and implementation of law, regulations, and public policies in three different ways:

i) When firms are connected to (former) Members of Parliaments (MPs), they may influence law and regulations enactment in their favor. Slinko et al. (2005) illustrate the legislative power of connected firms in Russia by detailing the budget law of Kamchatskaya Oblast of 2001, which provides large financial support to a single firm, Akros, among many others. In their attempt to measure the concentration of the political power of Russian firms, they show that at least $41 \%$ of firms in their sample benefit from legislation biased in their favor. Such biased legislation may offer firms various benefits, such as tax breaks, subsidized loan, and investment credits.

\footnotetext{
${ }^{4}$ In related empirical studies, Johnson and Mitton (2003) show that Malaysian firms personally tied to the executive have preferred access to subsidies. Adikari et al (2006) find similar evidences in Indonesia.

${ }^{5}$ See also Brezis (2014).

${ }^{6}$ See also Kaufmann, D. "Rethinking the Fight Against Corruption”, Brookings Opinion, 29/11/2012.
} 
ii) When firms are connected to (former) ministers and their advisers, they may influence the upstream formulation and implementation of policies and regulations, or take advantage from nonpublic information about the company or on the regulated industry (insider trading). For instance, in the UK, a former Defense minister and his permanent secretary have been disgraced for having taken a job with a Defense firm, AgustaWestland, with which the ministry signed a $£ 1.7$ billion contract while they were in office. They have indeed been found to have joined the defense company after having chosen it as a preferred bidder for a Ministry of defense's project, for which no other firms have been invited to bid.?

iii) When firms are connected to (former) high-level officials, they may influence the downstream implementation of regulations. As an illustration, the French "Mediator Affair" involved former officials of the French and European drug agencies prosecuted for unlawful behaviors when they unduly granted the marketing authorization of the Mediator. Indeed, they were accused of getting ludicrous contracts from Servier, the pharmaceutical group which commercialized the Mediator, after their leaving the public agencies they worked for. These officials, who became consultants for pharmaceutical industries, are suspected to have monetized this favor in exchange of various lucrative contracts. ${ }^{8}$

\subsection{Powerful firms, revolving door and economic distortions}

The literature on revolving door also focuses on the institutional configurations under which it generates economic distortions. Interestingly, the literature on state capture and political influence (Hellman and Kaufmann, 2002; Hellman et al. 2005; Slinko et al. 2005) supports that it is the concentration of political power among private firms which is the source of such economic distortions. These studies stress that a concentrated political power results into state capture by influential firms, which not only undermines trust in public institutions and property rights, but is also associated with lower levels of tax compliance, higher levels of bribery, and higher barriers to entry for small or less influential firms.

There have been some attempts to proxy economic distortions generated by the "inequality of influence" within the private sector. Hellman and Kaufmann (2004) propose a survey-based measure of crony bias reflecting "the extent to which firm managers believe that there are other actors with more or less influence than their own collective voice on the basic rules shaping their business environment" (Hellman and Kaufmann, 2004 p.101). Slinko et al. (2005) use the regional Herfindahl index of firms' preferential treatments incorporated into regional laws and regulations, as a proxy of the regional regulatory capture by politically powerful firms in Russia.

\footnotetext{
7 Jason Groves, "Disgraced Hoon gets top job at defence firm Westland - which landed $£ 1.7 \mathrm{bn}$ contract when he was Defence Secretary" in Dailymail the $18^{\text {th }}$ may 2011, http://bit.ly/jrSdSg.

8 "Mediator: l'enquête sur les conflits d'intérêts s'accélère" Le Point, February, 18, 2013, http://www.lepoint.fr/t/1-1629071. See also "Conflit d'intérêts: Aquilino Morelle visé par une enquête préliminaire" in Les Echos, April 22, 2014, http://po.st/IKK8Sx.
} 
Therefore, building on this literature, we hereafter present a small model explaining why some firms use the revolving more than other, and a measure of the risk of state capture induced by revolving door movements, the revolving door index (RDI).

\section{The RDI: theoretical foundations}

We present a small model illustrating how there can be concentration of revolvers in some specific firms, and how this inequality between firms can affect their profits. We develop the notion of bureaucratic capital, which is the way regulators get power over firms.

Indeed, conflicts of interests and State capture stem from the supply by the regulator of bureaucratic capital. Bureaucratic capital is the capital the bureaucrat creates while she is in the public service. The most common type of bureaucratic capital is investing in good relationships with the lower bureaucracy or accumulating a specific knowledge on the ins of the system, which are all valuable lawful behaviors in the future; but it can also consists in unlawful behaviors such as designing unnecessary complex regulations (red tape), regulations tailored to specific private interests, or influencing procurement or subsidy allowance processes towards specific firms.

In this market, the supply of bureaucratic capital is determined by each regulator, while the demand is determined by the firms. This bureaucratic capital will enter in firms' production function while the regulator is in office and after his term in office when the "revolved bureaucrats" or "revolvers" are hired by the revolving firm, leading to the capture of state resources (including regulations, public contracts, allowances, tax removals, etc.) through lawful and unlawful behaviors. This new market for bureaucratic capital will permit to explain why firms want to pay rents for hiring a previous regulator in their board.

We present some elements of theory explaining how the relative stock of bureaucratic capital brings value to the firm, which may lead to its concentration among few firms. In this configuration, the revolving door generates unfair competition, state capture and therefore distorts economies. Our model sets a monopolistic competition framework, in which regulated financial firms produce differentiated financial services and use bureaucratic capital, supplied by bureaucrats, as input in their production function.

\subsection{The regulators and the supply of bureaucratic capital}

The intermediate-goods sector consists of monopolistic firms and in consequence, they are regulated by the regulators. The regulators maximize the present value of their income, while the firms maximize profits.

During her time in office, the regulator regulates and receives an income, but at the same time, she creates bureaucratic capital - i.e. networks within public agencies, unnecessary complex regulations, influence in public resource allocation processes, knowledge of the ins-and-outs of the 
system, and so on. This bureaucratic capital is valuable to the firms in the financial industry, and thus, once she has left the public service, the regulator can cash-in on this bureaucratic capital.

The structure of the model is simple. During her term as a regulator, she acquires bureaucratic capital of size $H_{i}$, which costs her effort of size $E_{i}$ in monetary terms. Extending networks in public offices, creating red-tape, influencing the allocation of public resources, accumulating knowledge of regulations requires efforts, which are costly to the regulator ${ }^{9}$. The amount of bureaucratic capital created by $E_{i}$ units of effort of the regulator's employment as regulator is monotonically increasing and concave in the total amount of effort given by $h(E)$, with $\partial h / \partial E>0$ and $\partial^{2} h / \partial E^{2}<0$. We therefore assume that the level of bureaucratic capital is a concave function of the amount of effort invested, the same for all bureaucrats, which takes the specific form: ${ }^{10}$

$$
H_{i}\left(E_{i}\right)=\left[(1+\gamma) E_{i}\right]^{1 / 1+\gamma} \quad \gamma>0
$$

After leaving her job as regulator, the bureaucrat works for a period of length $\tau$, in the industry that she regulated. She receives in top of her "regular" salary a rent related to the "bureaucratic capital", $H_{i}$ she has accumulated.

The regulator maximizes her lifetime income which consists of (i) earnings which are not related to the creation of bureaucratic capital, denoted $\Omega$, and (ii) of income related to the creation of bureaucratic capital, which equals to the net income she gets when having entered the industry. After passing the revolving door, she will be able to sell her bureaucratic capital, $H_{i}$ at price q for a number of years $\tau$ so that her total income is:

$$
V_{i}=\Omega-E_{i}+\tau q H_{i}\left(E_{i}\right)
$$

Equation (2) can be rewritten as a function only of the level of bureaucratic capital, by substituting $E_{i}$ from equation (1). We get:

$$
V_{i}=\Omega-\frac{H_{i}^{1+\gamma}}{1+\gamma}+\tau q H_{i}
$$

From the point of view of the bureaucrat, there is an optimal level of bureaucratic power, $\hat{H}$ she wants to stock, which maximize her income - equation (3) and is:

\footnotetext{
${ }^{9}$ These costs consists of time spent in bureaucratic capital formation, and when unlawful behaviors are undertaken, these costs may encompass ethical costs, the social stigma, the probability of being caught and sanctioned.

${ }^{10}$ We are aware that for some bureaucrats, who are either more social, or with less "ethical values", it is easier to either create connection with other people, or create redundant regulations. For purpose of simplicity, we assume that bureaucrats have the same "production" function of bureaucratic capital, and that these social factors are not linked to ability, since removing this assumption does not affect the results. Moreover, the "effort" which describes either social or ethical costs, are in monetary terms.
} 


$$
\hat{H}_{i}=(\tau q)^{1 / \gamma}
$$

Equation (4) describes the "supply" function of bureaucratic capital by the regulator as an increasing function of the price $q$. We now turn to discuss the behavior of the firm and its demand for bureaucratic elite.

\subsection{The Demand of Bureaucratic Capital}

The business financial elite is composed of entrepreneurs, who are at the head of intermediategoods firms $j$, and who produce goods, $x_{j}$, in a monopolistic competitive environment. The output is a function of two factors of production. The first is capital, $k_{j}$. Following the standard Romer model, we assume that the production function takes the simple form:

$$
x_{j}=k_{j}
$$

However, in our model, the output $x_{j}$ is also function of a second factor of production, which is the level of bureaucratic capital accumulated by the regulator hired by the firm. This increase in the stock of bureaucratic capital $H_{j}$ results in an increase in production inasmuch firm $j$ has more bureaucratic capital than other firms. If all firms have the same amount of bureaucratic capital equilibrium situation which happens in the long run - then bureaucratic capital is useless for the firm. ${ }^{11}$ So, the production function in sector $s$ takes the form:

$$
x_{j}=k_{j}\left(\frac{H_{j}}{H_{a}}\right) \phi \quad \phi>0
$$

where $H_{j}$ is the level of bureaucratic capital produced by the regulator of firm $j$, and $H_{a}$ is the average level of bureaucratic capital owned by the other firms.

Note that if $H_{j}=H_{a}$, then the output is just $x_{j}=k_{j}$, no matter the average level of bureaucratic capital. This stems from the rent-seeking hypothesis developed in the literature review according to which the revolving door does not increase production through improved productivity but through rentseeking. If bureaucratic capital was a productivity factor, it would increase firm j's production, whatever the stock of bureaucratic capital accumulated by its competitors. This comes from the basic idea that, in a given sector, if each firm is as influent as its competitors, then using influence to increase production is useless. Therefore, although having hired a bureaucrat may bring an advantage over other firms from the firm $j$ point of view, it is pure waste from a social point of view.

\footnotetext{
${ }^{11}$ This model which emphasizes the relative amount of bureaucratic capital is therefore related to the concentration index we present in the next section.
} 
So, the profit maximization for an intermediate financial firm is:

$$
\operatorname{Max} \pi_{j}=p_{j}\left(x_{j}\right) x_{j}-r k_{j}-q H_{j}
$$

where $r$ is the cost of real capital, $k_{j ;}$ and $q$ the cost of the bureaucratic capital $H_{j}$, that is the remuneration given to the bureaucrat for bringing bureaucratic capital to the firm.

Each firm maximizes profits by finding the optimal amount of output, $x_{j}$ and bureaucratic capital $H_{j}$. Note that equation (6) can be rewritten in the following way:

$$
\operatorname{Max} \pi_{j}=p_{j}\left(x_{j}\right) x_{j}-r x_{j}\left(\frac{H_{j}}{H_{a}}\right)^{-\phi}-q H_{j}
$$

According to equation (7), firms get higher profits only if bureaucratic capital is unevenly distributed in their industry. In other words, over-performing firms exist because of the industrylevel concentration of bureaucratic capital in their hands. This notion of 'inequality' between firms underlies the construction of the revolving door index, which reflects the concentration of revolvers in only a small number of firms.

\section{The Revolving Door Index}

Following equation (7) and in line with the literature on state capture (Kaufman and Vincente, 2011; Slinko et al., 2005; Hellman and Kaufmann, 2004), we proxy the distortions created by the revolving door (RD) by measuring the sector concentration of revolvers and RD movements. According to our model, the distortive effects of the revolving door in the economy come from the uneven distribution of bureaucratic capital among firms in the private sector. Therefore, a high concentration of RD movement from firms to public agencies, and from public agencies to firms, indicates that this bureaucratic capital mostly accrue to few firms, thereby inducing a high risk of state capture.

In consequence, the Revolving Door Index (RDI) will be derived from a Hirschman- Herfindahl index formula. ${ }^{12}$ It measures the sector concentration of revolvers among private firms ${ }^{13}$, and is computed as follow for sector $s$ :

$$
R D I_{s}=100 \times \frac{\sqrt{\sum_{i=1}^{I}\left(\frac{r_{i}}{R_{s}}\right)^{2}}-\sqrt{1 / N_{s}}}{1-\sqrt{1 / N_{s}}}
$$

\footnotetext{
12 This Herfindahl is a rescaled and normalized version of the Herfindahl, and is, used by the UNCTAD to compute its export concentration index (UNCTAD 2013, p.212): http://unctad.org/en/PublicationsLibrary/tdstat38_en.pdf

${ }^{13}$ We will see in section IV.3.that another declination of the RDI may consist in focusing on public agencies as unit of analysis.
} 
The RDI is between 0 and 100. $R_{s}$ is the total number of revolved regulators in sector $s, r_{i}$ is the number of revolved regulators in firm $i$, and $N_{s}$ is the number of firms in sector $s$. The higher the index in sector $s$, the stronger the concentration of revolved regulators, and in consequence, the greater the distortions in sector $s$.

The RDI is expressed as the ratio of the difference between the actual Herfindahl and that of a competitive sector $(\sqrt{1 / N})$, over the difference between the Herfindahl of a monopolistic or monopsonistic sector and that of a competitive sector $(1-\sqrt{1 / N})$. Therefore, in some way this ratio can be interpreted as a share, so that a RDI of size $\lambda$ would mean that the allocation of bureaucratic capital is $\lambda \%$ of a perfectly concentrated market.

This index does not focus on the total amount of revolvers, and focuses only on the damaging effects of the revolving door by calculating the distortions between firms. We now turn to calculate the RDI for the banking sector.

\section{The RDI: empirical illustration}

We propose an empirical application of the RDI in the context of the US banking sector. US banks have indeed given over the last decades various and striking illustrations of how they used the revolving door to shape regulations to their own interests. We measure the concentration of revolvers - i.e. regulators engaged in the revolving door - among the top 5 biggest US commercial banks, ranked according to their total revenue in 2015: JPMorgan, Bank of America, Citigroup, Wells Fargo, and Goldman Sachs. Some of these large banks, commonly referred as "too-big-to-fail" banks, are known to massively use the revolving door to accumulate bureaucratic capital, and hence represent an interesting (although non representative) sample of firms for RDI calculations.

Raw information on revolvers and revolving door movements is collected from two important websites documenting the movements between the business and the bureaucracy in the US: Opensecret.org and Littlesis.org. Information on revolvers identity, revolving door movements, the position occupied in public and private offices is compiled, checked, corrected or completed using additional sources of information on revolvers' career: Linkedln webpage, Wikipedia, newspapers, business websites, SEC files, government agencies websites, and firms' own websites. The Appendix provides additional information on the data collection and treatment methodology. The resulting dataset covers a total of 236 revolvers involved in 299 revolving door movements, undertaken between 1933 and 2015, but mostly occurring in the 2000's. ${ }^{14}$

\footnotetext{
${ }^{14}$ The oldest revolving door movement we documented involves Sidney J. Weinberg, a.k.a "Mr. Wall Street", who was former executive of Goldman Sachs from 1927 to 1969, and who was simultaneously counselor at the White House from 1933 to 1969. See https://en.wikipedia.org/wiki/Sidney_Weinberg.
} 


\subsection{Typology of revolved regulators}

Individuals considered as revolvers are current (former) employees in private firms who are former (current) members of a US federal agency: ministry, parliament, or a relevant regulatory agency. ${ }^{15}$ We also identify individuals moving from (into) key agencies charged with financial matters: the Treasury, the White House, The Federal Deposit Insurance Company, the Commodity Future Trading Commission, intelligence agencies ${ }^{16}(\mathrm{FBI}, \mathrm{Cl} A, \mathrm{NSA})$, the Security and Exchange Commission, the Federal Reserve System, and the US Trade Representative ${ }^{17}$. Therefore, we collected information on revolvers' experience in these key regulatory agencies.

We focus on both private-to-public and public-to-private revolving door movements. While the model emphasizes how revolvers sell their bureaucratic capital after leaving public office, it is also common to see private sector officers cashing in huge exit bonanza before taking public responsibilities ${ }^{18}$. Therefore, three types of revolving door flows are identified:

- Type 1, public-to-private: former members of a relevant ministry, administration, or legislature currently hold an executive position in a regulated company.

- Type 2, private-to-public: former executives of a regulated company are currently members of a relevant ministry, administration, or legislature.

- Type 3, two-sided: when individuals undertake symmetric movements from a private firm to a public agency to the same private firm, or from a public agency to a private firm to the same public agency, they can favour firms both during and after their term in public office. Moreover, given the likelihood of agency capture in this configuration, two-sided RD movements are expected to yield additional value to the firm and are therefore counted threefold: one dummy for the public-to-private sector movement, on dummy for the private-to public-sector movement, and an additional dummy variable indicating this symmetric back-and-forth movement. Therefore, an individual undertaking this revolving door path is associated with three revolving door movements for the company.

\footnotetext{
${ }^{15}$ Local or State regulatory agencies - such as the NY housing regulatory agency - as well as foreign agencies - such as the European Central Bank - are therefore excluded from the analysis. However, the examination of the data showed that many firms hire revolvers that at some point of their career joined the Advisory Board of a local Federal Reserve Bank, especially the Federal Reserve Bank of New York, position that can be hold simultaneously with a job in the private sector. Given the many scandals that arose from the leakage Federal Reserve System's secret documents from the NY Fed towards financial firms, we considered individuals holding position in both private firms and local Federal Reserve Banks as revolvers. For similar concerns, we also consider as revolvers the many individuals that have integrated the 2008 Obama Transition Team while keeping their job in the private sector. See Appendix.

${ }^{16}$ Intelligence agencies play a key role in enforcing financial regulation and prosecuting cases of financial malpractices before the courts. The strong interest of financial firms in recruiting members of intelligence agencies can be illustrated by the recent hiring of Patrick Carroll, former FBI agent who headed securities fraud and white collar crime and who locked up Bernard Madoff , by Goldman Sachs. See http://fortune.com/2015/05/26/goldman-sachs-hire-fbi-agent/

${ }^{17}$ We also considered the US Trade Representative as a finance-related agency because of its key role for banks' implementation in foreign markets, notably through trade agreement negotiations.

18 See for instance Samantha Lachamn, "Hillary Clinton Backs Bill That Would Ban 'Golden Parachutes' For Wall Street Bankers", The Huff, Aug 31, 2015. http://www.huffingtonpost.com/entry/hillary-clinton-wall-street-goldenparachutes_us_55e44f14e4b0b7a9633974eb
} 
We should note that there exists also back-and-forth movements from a given public agency to a private agency and then to another public agency. From our point of view, they are counted twice separately: for each revolved regulator achieving this movement is associated one dummy variable equal to 1 when he has moved from the first public agency to the private financial company, one dummy variable when has moved from the financial company to the other public agency. Therefore, an individual undertaking this revolving door path is associated with two RD movements for the company.

Revolved regulators are also differentiated according to the influence and power of their (former) public sector positions: Influential revolvers are those who hold or have held top-level position in the government, in a relevant administration, or who have been members of parliament; while non-influential revolvers are those who hold or have held lower-level positions in the government or in a relevant administration.

The Appendix presents a more detailed description on data collection process and on the typology of revolving door movements.

\subsection{Anatomy of the revolving door: statistical highlights}

We now present key statistical highlights on the revolving door process that accrued to the five biggest commercial banks - JPMorgan, Citigroup, Goldman Sachs, Bank of America and Well Fargo - and that occurred over the last 80 years. ${ }^{19}$

Figure 1 shows that there were 236 revolvers engaged in 299 revolving door movements (types 1, 2 and 3 ), and that most RD movements (57\%) are public-to-private (type 1 ) ones. Only $6 \%$ of revolving door movements are two-sided. This small share is consistent with the sensitivity of such a revolving door path, which can be interpreted as explicit attempts by firms to capture specific agencies.

\footnotetext{
${ }^{19}$ The oldest revolving door movement we documented involves Sidney J. Weinberg, a.k.a "Mr. Wall Street", who was former executive of Goldman Sachs from 1927 to 1969, and who was counselor at the White House from 1933 to 1969. He notably advised Presidents Roosevelt, Eisenhower, Johnson. See https://en.wikipedia.org/wiki/Sidney_Weinberg.
} 


\section{Figure 1. The revolving door process in the five biggest US commercial banks}
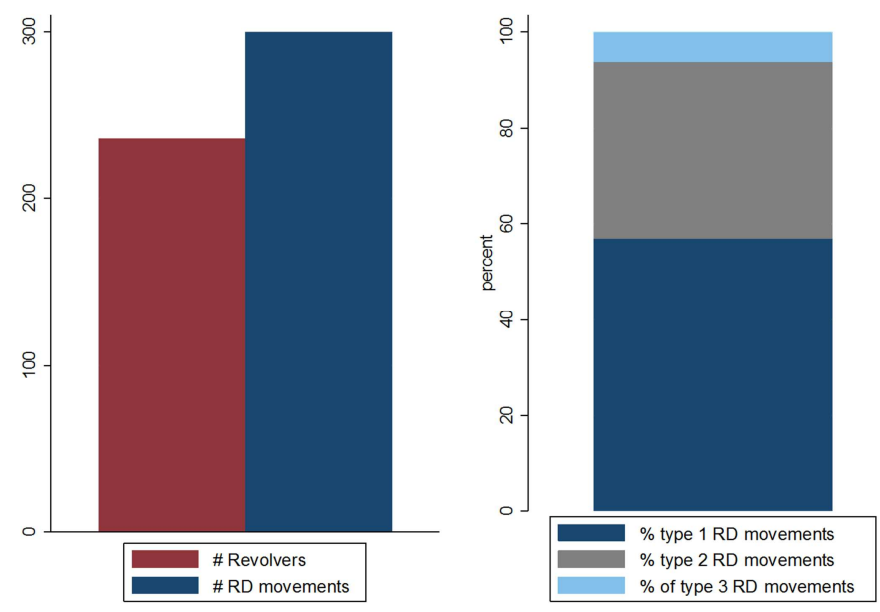

Figure 2 plots the distributions of private-to-public sector movements and public to private sector movements over time ${ }^{20}$. Most revolving door movements have occurred between 1990 and 2015. Private-to-public movements display two distribution modes located around 1992 and 2007-2008, while public-to-private movements display one distribution mode located around 2007-2008. Therefore, the beginning of the last financial crisis is concomitant with an intensity peak in revolving movements.

\section{Figure 2. Time distribution of revolving door movements}
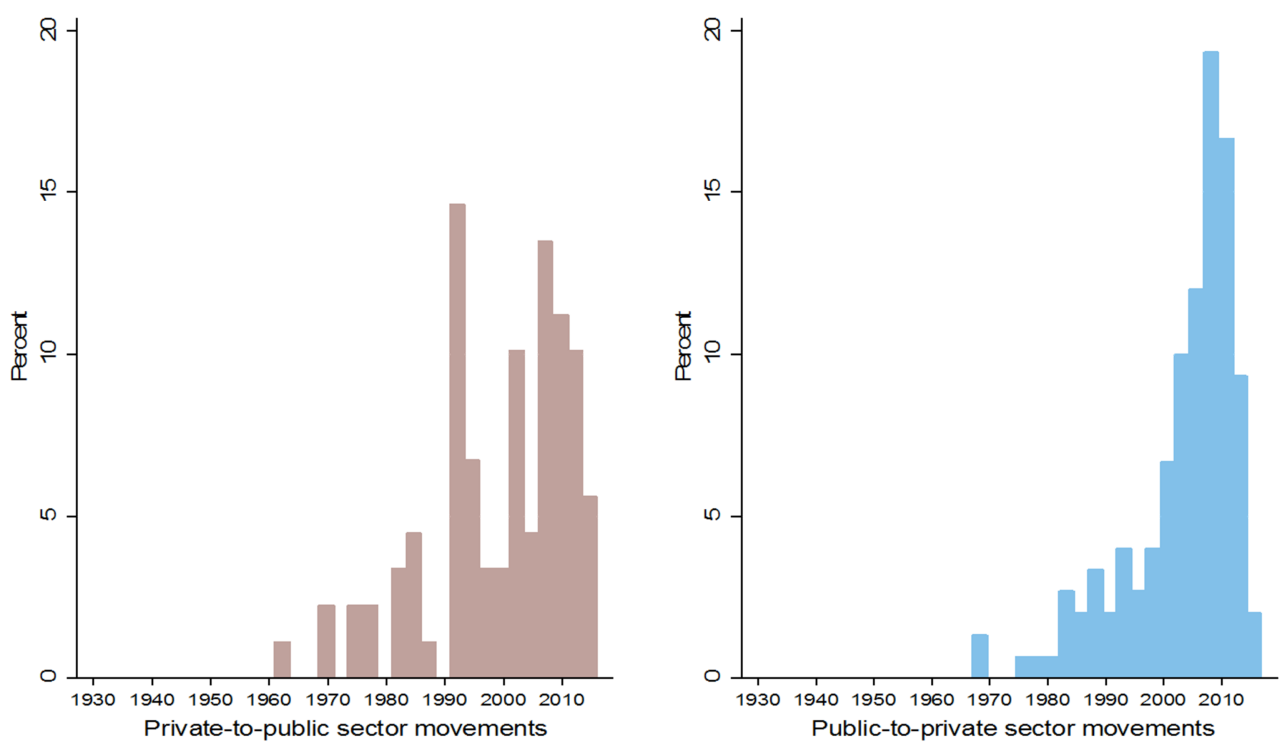

So as to have a further idea of how big banks are engaged in the RD process, we present a decomposition of the initial stock of revolvers and revolving door movements (Panel A) into sub-

${ }^{20}$ Two-sided revolving door movements are excluded from the distributions. 
movements (see table 1). This decomposition emphasizes movements of influential revolvers (Panel B), revolvers from key federal agencies (Panel C), and influential revolvers moving from/into key federal agencies (Panel D). We measure the concentration of each RD movement and submovement by computing its associated RDI, as well as the RDI variation with respect to its corresponding initial revolving door movement in Panel $\mathrm{A}$.

Table 1. The revolving door breakdown in five major US commercial banks

\begin{tabular}{|c|c|c|c|c|c|c|c|}
\hline & JPMorgan & BofA & Citigroup & Wells Fargo & $\begin{array}{c}\text { Goldman } \\
\text { Sachs }\end{array}$ & Total & RDI \\
\hline \multicolumn{8}{|c|}{ Panel A - general situation } \\
\hline \# revolvers & 59 & 29 & 55 & 12 & 81 & 236 & 9.96 \\
\hline $\begin{array}{l}\text { \# revolving door } \\
\text { moves }\end{array}$ & 78 & 36 & 71 & 12 & 102 & 299 & 10.79 \\
\hline $\begin{array}{l}\text { \# Public-to-private } \\
\text { moves }\end{array}$ & 47 & 22 & 41 & 10 & 50 & 170 & 7.96 \\
\hline $\begin{array}{l}\text { \# Private-to-public } \\
\text { moves }\end{array}$ & 26 & 12 & 25 & 2 & 45 & 110 & 16.03 \\
\hline \# two-sided moves & 5 & 2 & 5 & 0 & 7 & 19 & 15.73 \\
\hline \multicolumn{8}{|c|}{ Panel B - Influential revolvers } \\
\hline \# revolvers & 31 & 20 & 28 & 4 & 50 & 133 & 11.96 \\
\hline $\begin{array}{l}\text { \# revolving door } \\
\text { moves }\end{array}$ & 43 & 22 & 42 & 4 & 66 & 177 & 13.15 \\
\hline $\begin{array}{l}\text { \# Public-to-private } \\
\text { moves }\end{array}$ & 25 & 14 & 19 & 4 & 32 & 94 & 9.81 \\
\hline $\begin{array}{l}\text { \# Private-to-public } \\
\text { moves }\end{array}$ & 15 & 8 & 19 & 0 & 29 & 71 & 17.48 \\
\hline \# two-sided moves & 3 & 0 & 4 & 0 & 5 & 12 & 25.70 \\
\hline \multicolumn{8}{|c|}{ Panel C - Key Federal Agencies } \\
\hline \# revolvers & 37 & 16 & 39 & 3 & 58 & 153 & 14.56 \\
\hline $\begin{array}{l}\text { \# revolving door } \\
\text { moves }\end{array}$ & 50 & 21 & 52 & 3 & 77 & 203 & 15.01 \\
\hline $\begin{array}{l}\text { \# Public-to-private } \\
\text { moves }\end{array}$ & 28 & 11 & 30 & 3 & 38 & 110 & 12.97 \\
\hline $\begin{array}{l}\text { \# Private-to-public } \\
\text { moves }\end{array}$ & 18 & 8 & 18 & 0 & 33 & 77 & 18.80 \\
\hline \# two-sided moves & 4 & 2 & 4 & 0 & 6 & 16 & 15.04 \\
\hline \multicolumn{8}{|c|}{ Panel D - Influential revolvers from key fed agencies } \\
\hline \# revolvers & 23 & 14 & 23 & 1 & 40 & 101 & 14.80 \\
\hline $\begin{array}{l}\text { \# revolving door } \\
\text { moves }\end{array}$ & 33 & 15 & 36 & 1 & 54 & 139 & 15.85 \\
\hline $\begin{array}{l}\text { \# Public-to-private } \\
\text { moves }\end{array}$ & 18 & 9 & 17 & 1 & 28 & 73 & 14.40 \\
\hline $\begin{array}{l}\text { \# Private-to-public } \\
\text { moves }\end{array}$ & 12 & 6 & 15 & 0 & 22 & 55 & 17.17 \\
\hline \# two-sided moves & 3 & 0 & 4 & 0 & 4 & 11 & 24.40 \\
\hline
\end{tabular}

Compared to the other firms, Goldman Sachs, and in a lesser extent Citigroup and JPMorgan (hereafter called G-C-J), appear as major beneficiaries of RD movements. This evidence can also be related by their status of "too-big-to-fail" banks which probably make them to be the main 
demanders on the bureaucratic capital market. As a result, this distribution displays relatively low concentration patterns, with a RDI around $10-15 \%$ (see panel A). We now show that concentration becomes more acute when we break down revolving movements into various typologies.

Indeed, the uptake of bureaucratic capital by G-C-J becomes striking when we restrict the sample to influential revolvers only, when we look at movements involving key federal agencies, and when we focus on two-sided RD movements. In fact, two-sided movements of influential revolvers, particularly influential revolvers from key federal agencies, display the highest concentration scores (of around $26 \%$ and $24 \%$ ).

Moreover, the concentration of type-1 RD movements- i.e. public-to-private movements - from key federal agencies (panels $C$ and $D$ ) is the one presenting the highest divergence from the general situation (panel A). These movements' concentration in panel $C$ significantly increases compared to type $1 \mathrm{RD}$ movements in panel $\mathrm{A}$, and almost double when we focus on type-1 movements of influential revolvers from key federal agencies.

Thus, this brief anatomy of the revolving door among the five biggest US commercial banks show that, despite of the restrictiveness of our sample of firms, the concentration of bureaucratic capital increases when the emphasis is placed on features of the RD expected to yield significant value to the firm - the influence of revolvers, the agency membership, and the direction of revolving door movements; and that these concentration patterns mostly benefit to Goldman Sachs, JPMorgan and Citigroup.

\subsection{Ways forward}

Our theoretical formalisation of the bureaucratic capital market led us to emphasize the concentration of revolving door movements within the various firms of the banking sector. One drawbacks of our approach is that it partly eludes what is happening within the public sector. The following sub-section tries to lift the veil on the creation of bureaucratic capital within public agencies, which could, in fine, enable policymakers to identify effective safeguards against drifting of the revolving door process.

\subsubsection{Measuring agency capture}

In our model, we focus on one agency regulating one specific firm. However, the reality is more complex, and there are many agencies which have a say on the regulation of sectors, especially the financial sector. It is therefore interesting to check the public agencies from which there are RD movements to the banking sector.

Table 2 displays the distribution of revolvers and RD movements from the five biggest US banks among key federal public agencies regulating the financial sector. We observe that among the 299 total revolving door movements, $68 \%$ of RD movements are related to nine agencies. Among these 
flows, $30 \%$ of RD movements are connected to the Federal Reserve System, $18 \%$ of RD movements are connected to the Treasury, and $12 \%$ of RD movements are connected to the White House. ${ }^{21}$

Table 2. The revolving door breakdown in the nine key federal agencies

\begin{tabular}{|c|c|c|c|c|c|c|c|c|c|c|c|}
\hline & $\begin{array}{l}\text { White } \\
\text { House }\end{array}$ & Treasury & SEC & $\begin{array}{c}\text { Fed } \\
\text { System }\end{array}$ & FDIC & $\begin{array}{c}\text { Congress } \\
\text { bank \& } \\
\text { finance } \\
\text { Committees } \\
\end{array}$ & CFTC & $\begin{array}{c}\text { Intelligence } \\
\text { agency }\end{array}$ & $\begin{array}{l}\text { US } \\
\text { Trade } \\
\text { Rep }\end{array}$ & Total & RDI \\
\hline \multicolumn{12}{|c|}{ Panel A - reference situation } \\
\hline $\begin{array}{l}\text { \# revolvers } \\
\text { \# revolving }\end{array}$ & 24 & 35 & 12 & 38 & 6 & 18 & 3 & 9 & 8 & 153 & 11.25 \\
\hline $\begin{array}{l}\text { door moves } \\
\text { \# Public-to- }\end{array}$ & 33 & 48 & 17 & 59 & 7 & 18 & 3 & 10 & 8 & 203 & 14.88 \\
\hline $\begin{array}{l}\text { private moves } \\
\text { \# Private-to- }\end{array}$ & 19 & 28 & 8 & 20 & 2 & 16 & 1 & 8 & 8 & 110 & 10.95 \\
\hline $\begin{array}{l}\text { public moves } \\
\text { \# two-sided }\end{array}$ & 11 & 16 & 7 & 32 & 5 & 2 & 2 & 2 & 0 & 77 & 25.12 \\
\hline moves & 3 & 4 & 2 & 7 & 0 & 0 & 0 & 0 & 0 & 16 & 32.80 \\
\hline \multicolumn{12}{|c|}{ Panel B - Influential revolvers } \\
\hline $\begin{array}{l}\text { \# revolvers } \\
\text { \# revolving }\end{array}$ & 18 & 23 & 11 & 25 & 2 & 6 & 3 & 8 & 5 & 101 & 11.90 \\
\hline $\begin{array}{l}\text { door moves } \\
\text { \# Public-to- }\end{array}$ & 25 & 36 & 14 & 39 & 2 & 6 & 3 & 9 & 5 & 139 & 16.46 \\
\hline $\begin{array}{l}\text { private moves } \\
\text { \# Private-to- }\end{array}$ & 15 & 20 & 7 & 14 & 0 & 4 & 1 & 7 & 5 & 73 & 13.70 \\
\hline $\begin{array}{l}\text { public moves } \\
\text { \# two-sided }\end{array}$ & 8 & 12 & 6 & 21 & 2 & 2 & 2 & 2 & 0 & 55 & 22.21 \\
\hline moves & 2 & 4 & 1 & 4 & 0 & 0 & 0 & 0 & 0 & 11 & 32.95 \\
\hline \multicolumn{12}{|c|}{ Panel C - Systemic revolvers ${ }^{a}$} \\
\hline $\begin{array}{l}\text { \# revolvers } \\
\text { \# revolving }\end{array}$ & 5 & 11 & 2 & 13 & 2 & 2 & 0 & 4 & 2 & 41 & 18.15 \\
\hline $\begin{array}{l}\text { door moves } \\
\text { \# Public-to- }\end{array}$ & 6 & 16 & 4 & 23 & 3 & 2 & 0 & 4 & 2 & 60 & 23.74 \\
\hline $\begin{array}{l}\text { private moves } \\
\text { \# Private-to- }\end{array}$ & 2 & 8 & 1 & 8 & 1 & 1 & 0 & 4 & 2 & 27 & 19.17 \\
\hline $\begin{array}{l}\text { public moves } \\
\text { \# two-sided }\end{array}$ & 4 & 7 & 2 & 10 & 2 & 1 & 0 & 0 & 0 & 26 & 26.10 \\
\hline moves & 0 & 1 & 1 & 5 & 0 & 0 & 0 & 0 & 0 & 7 & 61.35 \\
\hline
\end{tabular}

a. Systemic revolvers are individuals that have worked in at least 2 of the five banks of our sample.

In consequence, we compute a public-sector declination of the Revolving Door Index, switching the unit of analysis from the firm to the regulatory agency:

$$
R D I_{a}=100 \times \frac{\sqrt{\sum_{j=1}^{K}\left(\frac{r_{a}}{R_{s}}\right)^{2}}-\sqrt{1 / N_{a}}}{1-\sqrt{1 / N_{a}}}
$$

The $\mathrm{RDI}_{\mathrm{a}}$ is again between 0 and 100. $R_{s}$ is the total number of revolved regulators in sector $s, r_{a}$ is the number of revolved regulators in agency $a$, and $N_{a}$ is the number of agencies targeted or

\footnotetext{
${ }^{21}$ In terms of revolvers (and not movements), it is slightly lower, see Table 2.
} 
"captured" by sector s. A high concentration of entry and exit movements of revolvers from specific agencies indicates a high concentration in bureaucratic capital creation, inducing a high risk of agency capture by sector $s$.

At first sight, revolving door concentration patterns (RDI values) for the general case is not different than the results in Table 1 (Panel A, bold numbers). We get an RDI of 14.88 for the total and of 32.80 for the two-sided moves. However, when we focus on what we define as systemic revolvers (revolvers that undertook two-sided back-and-forth movements), then the RDI for two-sided moves is of 61.35. This high RDI is due to the fact that the two-sided movements are almost all concentrated within the Fed (see Panel C, last row).

\subsubsection{Regulating the revolving door}

Our index has permitted to pinpoint the loopholes of the revolving door, although we are aware that there is a need for even more data. It is clear that by measuring the sectorial concentration of the revolving door, the RDI is a first step to size up the distortive power of the revolving door, and will permit over time to compare progresses made by the government in implementing safeguards against the risks of conflict of interest associated with promiscuous public and private elites.

The effect of policies and regulations aimed at controlling the revolving door should be reflected in RDI values in various ways. For instance, post-employment restrictions requiring a minimum "cooling-off" period after public office, by slowing down public-to-private and two-sided revolving door flows, should reduce the influence of revolved regulators over public decision-making after their term in public office. Their value for captor firms should therefore decrease, as well as the incentives to hire them for rent-seeking purpose. As a consequence, the concentration of publicto-private revolving door flows would be reduced.

Regarding private-to-public revolving door flows (in which the RDI is quite high), pre-employment restrictions preventing former private sector employees from undertaking certain tasks in the public sector should somehow incite captor firms' staff to refrain from entering the public sector. Empowered commissions on civil service, and rules of transparency (such as asset disclosure for parliamentarians and ministers) should also drag down the concentration of revolved regulators by decreasing the value of revolved regulators for rent-seeking firms.

In conclusion, our RDI calculation is a first step to estimate conflicts of interests and state capture induced by the revolving door. 


\section{Conclusion}

In the last decade, the economic literature as well as the media have stressed that the revolving door has negative effects on the economy, and it was even connected to the crisis affecting the financial sectors from 2008 and on.

The literature has stressed that the revolving door process i) is a major source of political connections for private firms operating in industrialized and emerging economies, ii) is related to specific corruption risks during the enactment and implementation of laws and regulations, and iii) adversely affects economic outcomes.

It is quite clear that, unfortunately, regulations of the revolving door process are scarce and when they exist, they are often poorly enforced. Moreover, the revolving door still beneficiates from a great tolerance of the public for it (although decreasing these last years), partly due to a lack of measurement for its prevalence and impact on economies. Indeed, there have been no attempts to use objective data in order to build an actionable and internationally comparable proxy measure of the distortions created by the revolving door process.

This paper presents an index which permits to quantify the distortionary effects of the revolving door. We first have presented a simple model which is the underlying motivation for this specific formulation of the RDI. In our model, public agents create bureaucratic capital during their term in public office, and the revolving door allows them 'selling' this bureaucratic capital to private firms. In fact, this model stresses that, although having hired a bureaucrat may give an advantage to a given firm over its competitors, it is pure waste from a social point of view. Therefore, the revolving door distorts sectors in which revolvers are unevenly distributed. This is the rationale for our RDI index: a normalized Herfindahl of the concentration of the revolving door movements at the sector level.

As an illustration, we have applied the RDI to the US banking sector, and measured the concentration of revolvers - i.e. regulators engaged in the revolving door - among the top 5 biggest US commercial banks, commonly referred as "too-big-to-fail" banks. Our data show that the concentration of bureaucratic capital increases when the emphasis is on influential civil servants. Moreover, these concentration patterns mostly benefit to Goldman Sachs, and in a lesser extent to JPMorgan and Citigroup. We also highlight that the Federal Reserve System, the Treasury, and to a lesser extent the White House, are the administrations mostly prone to be captured by banks.

Therefore, the Revolving Door Index (RDI) is an insightful measure of the distortions induced by the revolving door process. It also appeared that the RDI can be used as a tool for assessing the effectiveness of pre and post-employment restrictions, for raising awareness on the need of regulating the market for bureaucratic capital, and therefore for reducing the risk of conflict of interests induced by this process. 


\section{REFERENCES}

- Adhikari, A., Derashid, C., \& Zhang, H. (2006). Public policy, political connections, and effective tax rates: Longitudinal evidence from Malaysia. Journal of Accounting and Public Policy, 25, 574-595.

- Amore, M.D., \& Bennedsen, M.(2013). The value of political connections in a lowcorruption environment. Journal of Financial Economics, 110, 87-402.

- Ansolabehere, S., Figueiredo, J.M., \& Snyder, J.M. (2003). Why is There so Little Money in U.S. Politics?. Journal of Economic Perspectives, 17(1),105-130.

- Bertrand, M., Kramarz, F., Schoar, A., \& Thesmar, D. (2006). Politicians, firms and the political business cycle: evidence from France. Working Paper, University of Chicago.

- Boubakri, N., Guedhami, O., Mishra, D., \& Saffar, W. (2012). Political connections and the cost of equity capital. Journal of Corporate Finance, 18,541-599.

- Brezis, E.S. (2013). Promiscuous Elites, the Revolving Door, and Economic Growth. Working Paper Series, Bar-Ilan University, Israël.

- Brezis, E.S., \& Weiss, A. (1997). Conscientious regulation and postregulatory employment restrictions. European Journal of Political Economy, 13, 517-536.

- Brezis, E.S., Paroush, J., \& Weiss, A. (2002). Red tape: Oiling the Hinges of the 'Revolving Door. Working Paper Series, Bar-Ilan University, Israël.

- Chen, M.X. (2013). The matching of heterogeneous firms and politicians. Economic Inquiry, 51(2), 1502-1522.

- Cingano, F., \& Pinotti, P. (2013). Politicians at work: the private returns and social costs of political connections. Journal of the European Economic Association, 11(2), 433-465.

- Faccio, M. (2006). Politically connected firms. The American Economic Review, 96, 369-386.

- Faccio, M. (2010). Differences between Politically Connected and Nonconnected Firms: A Cross-Country Analysis. Financial Management, 39(3), 905-927.

- Faccio, M., Masulis, M.W., \& McConnell, J.J. (2006). Political Connections and Corporate Bailouts. Journal of Finance, 61(6), 2597-2635.

- Fisman, R. (2001). Estimating the Value of Political Connections. The American Economic Review, 91(4), 1095-1102.

- Goldman, E., Rocholl, J., \& So, J. (2013). Politically Connected Boards of Directors and the Allocation of Procurement Contracts. Review of Finance, 17(5), 16171648.

- Hellman, J., \& Kaufmann, D. (2004). The Inequality of Influence. In J. Kornai and S. Rose-Ackerman (Eds.), Building a Trustworthy State in Post-Socialist Transition, Palgrave Macmillan, New York.

- Hellman, J., Jones, G., \& Kaufmann, D. (2003). Seize the state, seize the day: state capture and influence in transition economies. Journal of Comparative Economics, 31, 751-773.

- Johnson, S., \& Mitton, T. (2003). Cronyism and capital controls: evidence from Malaysia. Journal of Financial Economics, 67, 351-382.

- Khwaja, A.I., \& Mian, A. (2005). Do Lenders Favor Politically Connected Firms? Rent Provision in an emerging Financial Market. The Quarterly Journal of Economics, 120(4), 1371-1411. 
- Kane, E.J. (2014). Comment on: the revolving door and worker flows in banking regulation by D. Luca, A. Seru, and F. Trebbi. Journal of Monetary Economics, 65, 33-35.

- Kaufmann, D., \& Vicente, P.C. (2011). Legal corruption. Economics \& Politics, 23(2), 195-219.

- Kramarz, F., \& Thesmar, D. (2013). Social network in the boardroom. Journal of the European Economic Association, 11(4), 780807.

- Laffont, J. J. \& Tirole, J. (1996), A Theory of Incentives in Procurement and Regulation. Cambridge, MA: The MIT Press.

- Lucca, D., Seru, A., \& Trebbi, F. (2014). The revolving door and worker flows in banking regulation. Journal of Monetary Economics, 65, 17-32.

- Luechinger, S. \& Moser, C. (2014). The Value of the Revolving Door: Political Appointees and the Stock Market. Journal of Public Economics, 119, 93-107.

- Murphy, K.M., Shleifer, A., \& Vishny, R.W. (1991). The Allocation of Talent: Implication for Growth. The Quarterly Journal of Economics, 106(2), 503-530.
- OCDE (2009). Revolving Doors, Accountability and Transparency Emerging Regulatory Concerns and Policy Solutions in the Financial Crisis. Public Governance Committee, Paris.

- Rajan, R., \& Zingales. L. (1998). Which capitalism? Lesson from the East Asian Crisis. Journal of Applied Corporate Finance, $11,40-48$.

- Slinko, I., Yakovlev, E., \& Zhuravskaya, E. (2005). Law for Sale: Evidence from Russia. American Law and Economics Review, 7(1), 284-318.

- Transparency International (2011). Cabs for hire? Fixing the revolving door between government and business. Transparency International UK.

- United Nations Conference on Trade and Development (2013). Handbook of Statistics. United Nations: New York and Geneva. 


\section{APPENDIX - METHODOLOGICAL NOTES}

The top 5 commercial banks are selected according to the Fortune 500 rankings of commercial banks (with regard to their total revenue). Other famous financial firms strongly involved in the revolving door - such as Fannie Mae, or Freddie Mac - are diversified financial firms and are therefore not included in the sample.

The main raw data sources are on the one hand, the Opensecrets.org website, managed by the Center for Responsive Politics, and on the other hand, Littlesis.org. Opensecrets.org and Littlesis.org provides open-access and documented information on the revolving door process and lobbying in the US political system. ${ }^{22}$ Primary raw data on the revolving door in the top 5 US commercial banks is therefore drawn from these two websites. Information on revolving door career path is then cross-checked, further documented, corrected when necessary, by complementary information drawn from Linkedin, Wikipedia, muckety.org, Beyond.com, zoominfo.com, Bloomberg.com, Businessweek, Business Insider, journal articles and other web sources. When this additional source cannot confirm entry-exit dates in the public and private sectors, dates provided by open secret are taken. If multiple converging additional sources diverge with Opensecrets entry-exit dates, the former are taken into account.

Once data is retrieved and cross-checked, a second round of data collection is undertaken, by searching on google potential additional revolved regulators using the following association of keywords: "name of the company + revolving door", "name of the company + political appointment", "name of the company + lobbyist".

\section{Data treatment}

Revolvers are sorted by the influence and power of their government positions. For those individuals with complex careers and had been in a government position multiple times, the positions that were taken in account are the most influential positions during revolvers' careers.

Influential positions considered are the following:

- Chairman of the Federal Reserve, and New York's Fed

- Chief of Staff to the White House

- White House: Assistant to the President, congressional liaison

- Chief of Staff/ Assistant Secretary of Treasury

- Congressmen

${ }^{22}$ see for instance Ansolabehere, S., et al. (2003). 
- Deputy/Director of the National Economic Council

- Chairman and directors of the Securities and Exchange Commission (SEC)

- Managing Executive of SEC's Division of Enforcement

- Chief of Staff/Chairman of Commodities Futures Trading Commission

- Deputy Secretary/Secretary/Assistant Secretary/Under Secretary of US State Department

- Secretary of Navy

- Secretary of Treasury

- Ambassador

- Head/Deputy of the Office of the United States Trade Representative

- Chief of Staff to President's Council of Economic Advisors

- Director of Office of Management and Budget

- Director of Congressional Budget Office

- National Security Advisor

- Attorney General (Deputy)

- Consul to the President

- State Governors

- Chief of Staff to Chairman of the US Consumer Product Safety Commission

- Director, chief of staff of the Federal Housing Finance Agency

- Director, chief of staff of the Federal Deposit Insurance Corporation

- Member of the Congress' Finance Committee

All other positions in federal agencies, boards or commissions are less influential. Positions in local agencies, commissions or boards are not considered, except for members of advisory boards of local agencies of the Federal Reserve System and chief of staff of State governors, who are recorded as less influential revolvers.

The specific case of the Obama-Biden 2008 transition period: This period allowed many banks' employees integrating Obama transition team without imposing them to leave their position in the 
private financial sector. We nevertheless consider the membership to this team as less influential position in public office.

Former employees of WaMu, Chase Manhattan Bank, Dime Bancorp and Bank One are considered as part of JP Morgan stock of revolvers. Former employees of Primerica and Travelers group are considered as part of Citigroup stock of revolvers. Former employees of Merrill Lynch and Security Pacific Bank are considered as part of Bank of America stock of revolvers. Former employees of West One Bank are considered as US Bancorp's stock of revolvers.

\section{The coding of revolving door back-and-forth movements}

Movements from a given public agency to a private to another public agency are counted twice separately: for each revolved regulator achieving this movement is associated one dummy variable equal to 1 when he has moved from the first public agency to the private financial company, one dummy variable when has moved from the financial company to the other public agency. Therefore, an individual following this revolving door path is counted twice for a given company.

However, back-and-forth movements from a private firm to a public agency to the same private firm, or from a public agency to a private firm to the same public agency, are expected to yield additional value to the firm. They are therefore counted threefold: one dummy for the public to the private sector movement, on dummy for the private to public sector movement, and an additional dummy variable indicating this symmetric back-and-forth movement. Therefore, an individual following this revolving door path is counted threefold for a given company. 

"Sur quoi la fondera-t-il l'économie du monde qu'il veut gouverner? Sera-ce sur le caprice de chaque particulier? Quelle confusion! Sera-ce sur la justice? Il l'ignore."

Pascal

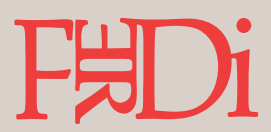

Created in 2003, the Fondation pour les études et recherches sur le développement international aims to promote a fuller understanding of international economic development and the factors that influence it.

\section{$\hookrightarrow$ Contact}

www.ferdi.fr

contact@ferdi.fr

+33 (o)4 73177530 